症例

リンパ節転移との鑑別を要す亜急性壊死性リンパ節炎を併発した 乳腺 glycogen-rich clear cell carcinoma の 1 例

\author{
札幌乳腺外科クリニック，札幌臨床検査センター* \\ 佐藤文彦岡崎稔岡崎亮 \\ 渡 部 芳 樹成 松 英 明*
}

症例は50歳, 女性. 平成21年 9 月 3 日の検診マンモグラフィ $(\mathrm{MMG})$ で，右乳房に 5 $\mathrm{mm}$ 大の異常陰影を指摘され，前医を受診。再検 MMG では異常を認めず，超音波検査

(US) で対側の左乳房 C 領域に $1.4 \mathrm{~cm}$ 大の腫瘍が検出され, 穿刺吸引細胞診 (FNAC) で悪性の疑いとされた。精査・加療を目的として当院を受診した.

当院受診時の FNACにて乳癌の確定診断を得たが，腋窩および鎖骨上に腫大したリ ンパ節を触知した。高度のリンパ節転移が疑われたがUS上の腫瘍径とリンパ節所見と の間にやや乘離が感じられた。このため, 腋窩リンパ節の FNAC を行ったが転移確定に は至らなかった。入院後, 左乳房温存手術 $(1 \mathrm{t}-\mathrm{Bp}+\mathrm{Ax})$ を施行した。病理組織診断で glycogen-rich clear cell carcinoma (GRCCC) との結果で，リンパ節は subacute necrotizing lymphadenitisであり転移はなかった。

索引用語： glycogen-rich clear cell carcinoma，亜急性壊死性リンパ節炎

\section{緒言}

乳腺 glycogen-rich clear cell carcinoma (GRCCC) は，全乳癌の $0.9 \sim 3 \%{ }^{12)}$ と比較的まれな乳腺悪性腫 瘍である.本邦でもその臨床像の報告が散見され,徐久 に症例が蓄積されつつある。組織学的には多量のグリ コーゲンを含んだ淡明な細胞質を有した癌細胞が，90 \%以上の面積を占めるものとされ，その予後は，通常 の浸潤性乳管癌に比して不良との報告が多い3)が，一 定の見解はない.

一方，悪急性壊死性リンパ節炎は予後良好なリンパ 節炎で, ウィルス感染や自己免疫が病因として挙げら れるが，いまだ不明な点が多い。

今回, 乳癌と同側の腋窩リンパ節群に悪急性壊死性 リンパ節炎を併発し，転移との鑑別を要した GRCCC の 1 例を経験したので，若干の文献的考察を加えて報 告する.

\section{症例}

症例：50歳，女性.

2011年 1 月 7 日受付 2011 年 2 月 16 日採用

〈所属施設住所〉

０60-0006 札幌市中央区北六条西19丁目22-6
主訴: 左乳腺腫瘍.

既往歴：子宮筋腫.

家族歴：特記すべきことなし。

現病歴：平成 21 年 9 月，乳がん検診を受け右マンモ グラフィ（以下 $\mathrm{MMG}$ ) で $5 \mathrm{~mm}$ 大の陰影を指摘され, 前医を受診。再検 $M M G$ では両側カテゴリー 1 であっ たが，US 上対側左乳房 C 領域に非触知の $1.4 \mathrm{~cm}$ 大の 低エコー腫瘍が検出された。穿刺吸引細胞診（以下 FNAC) では乳癌疑いの結果で, 精査・加療を目的と して当院を受診した。

初診時身体所見：触診上，乳房に腫瘤・硬結を触知 せず，皮膚にも異常はなかった，左腋窩および鎖骨上 窩に腫大したリンパ節を複数触れたが同部に圧痛はな く，発熱の既往もなかった。また，他の部位に表在り ンパ節を触知しなかった。

MMG 所見：明らかな腫瘤陰影や構築の乱れや石灰 化を認めず，両側カテゴリー1であった。

US 所見：左乳房 C 領域に, $1.4 \times 1.0 \times 1.1 \mathrm{~cm}$ 辺緑 不明瞭で不整形, 内部不均一の低エコー腫瘍を認め

(Fig. 1a)，近接してその内側に0.6cm 大の低エコー 腫瘍も検出した。また，左腋窩に最大 $2 \mathrm{~cm}$ 大に腫大 し，内部エコーが粗雑なリンパ節を複数認め（Fig. 

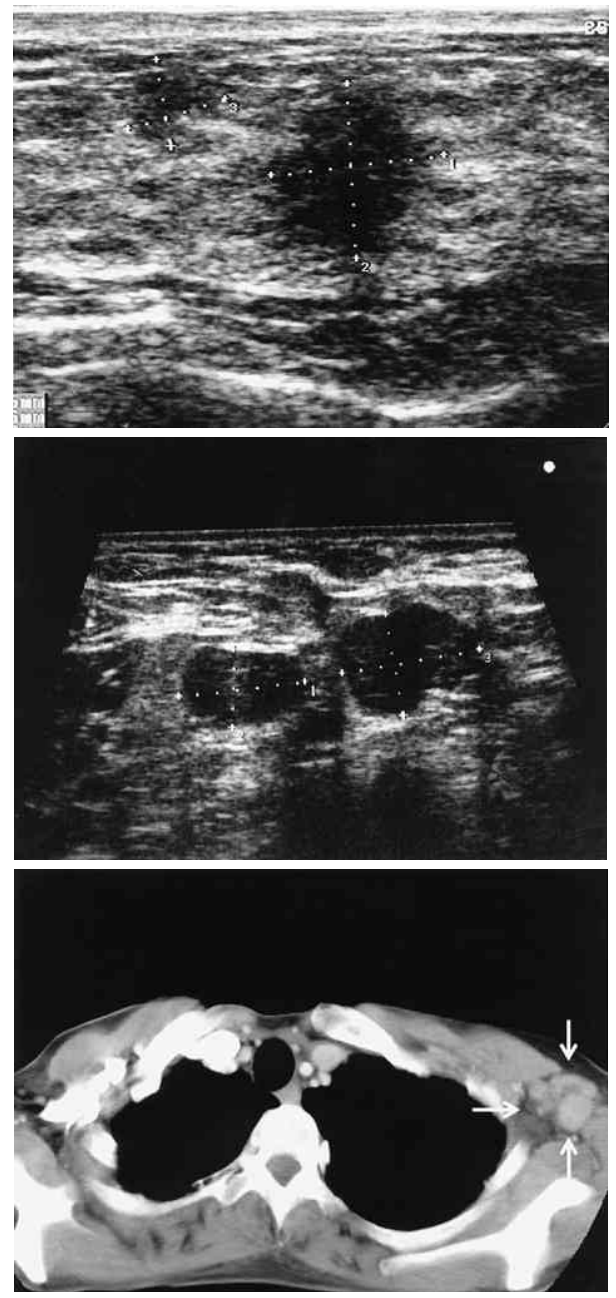

Fig. 1 a ) US shows an irregularly shaped, heterogenous, hypoechoic tumor $(1.4 \times 1.1 \times$ $1.1 \mathrm{~cm})$.

b ) US shows multiple swollen lymph nodes in the left axillary space.

c ) Computed tomography also shows multiple swollen lymph nodes.

$$
\frac{\mathrm{a}}{\mathrm{b}}
$$

1b)，鎖骨下および鎖骨上にも同様のリンパ節を検出 した.

CT 所見：両側肺および肝臓内に，転移所見はなか った. 左腋窩に複数の腫大リンパ節が描出された $(\mathbf{F i g}$. 1c).

穿刺吸引細胞診所見：腫瘍本体の細胞は中型で，淡 明で比較的広い細胞質を有し，核は偏在傾向を示し核

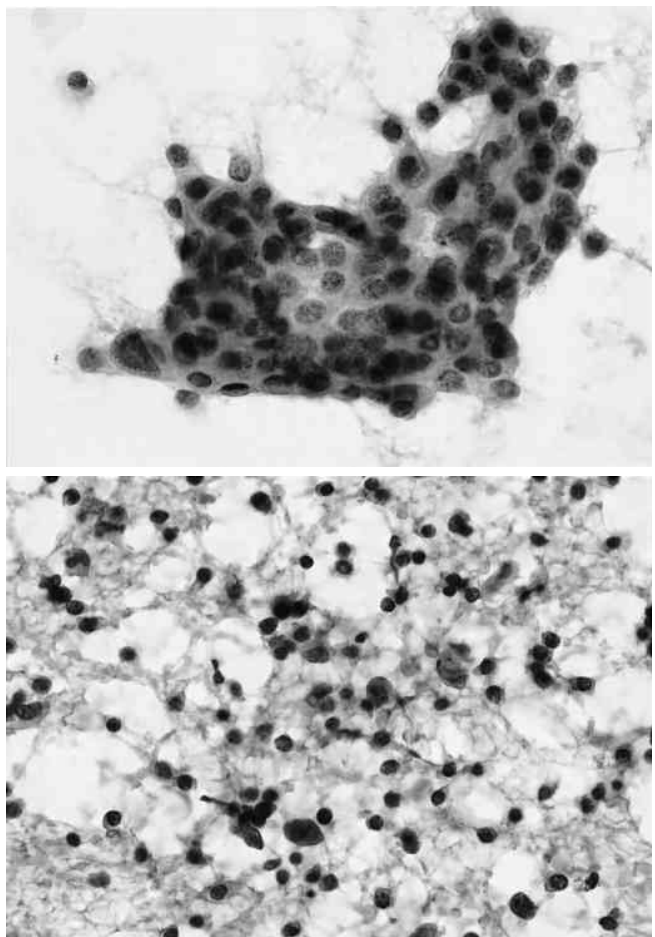

Fig. 2 Cytology of the original left breast tumor (a) and the axillary lymph node (b). (Pap. stain $\times 400)$

a) Medium-sized tumor cells with hyperchromatic nuclei and clear cytoplasm are seen. The nuclei are pleomorphic.

b ) No epithelial cells or atypical lymphocytes are seen.

$\frac{\mathrm{a}}{\mathrm{b}}$

型・核縁不整で大小不同を認めクロマチンの増量がみ られ，悪性の判定であった（Fig. 2a）。

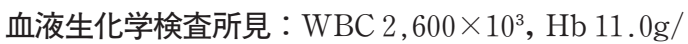
dl, BUN 7.2mg/dl, 血清鉄 $9 \mu \mathrm{g} / \mathrm{dl}$, LDH 260U/L. 軽度の貧血と白血球減少を認めたが，白血球分画に異 常はなかった。

Gd-MRI 所見：(当院の乳房 Gd-MRI は，仰臥位・ 冠状断・MIP 画像・ステレオ視を用いている.）早期か ら enhance される不整形腫瘍が描出され, 比較的限局 性でわずかに周囲への乳管内進展を示す enhancement を認めた. US の所見に一致して, 内側の小病巣 も描出された（Fig. 3).

細胞診で, 左乳腺腫瘍について乳癌の確定診断を得 たが，腋窩〜鎖骨上リンパ節がすべて転移性の腫脹と 


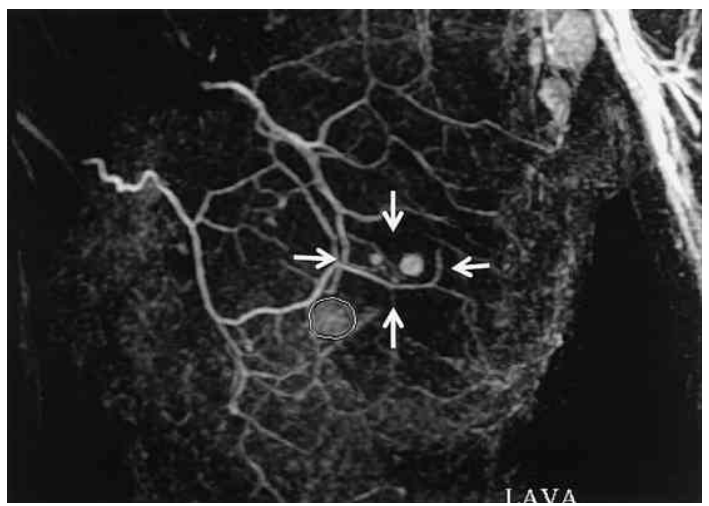

Fig. 3 MRI (Gd-enhanced, facing upward, coronal, MIP) shows two strongly enhanced lesions suggestive of comparatively localized cancer.

考えると，腫瘍のサイズに比してかなり高度な転移を 呈していることとなり, やや不自然さを感じた。 また， 触診所見もリンパ節は高度な硬さを呈しておらず，反 応性腫大やリンパ系疾患等の転移以外の可能性も否定 できなかった。

そこで，腋窩の最大のリンパ節に対して FNACを 行った。結果は陰性で，上皮細胞や異型リンパ球は見 られず，転移か否かの確定診断は困難であった（Fig. $2 b)$.

これらの所見から入院後平成 21 年 9 月, 乳房温存手 術を行い，腋窩浅部の腫脹リンパ節 2 個を術中迅速組 織診に提出した。結果は no malignancy で，転移所見 や異型リンパ球は認めず，反応性の腫大がもっとも考 えられる，との報告であった。転移の可能性は低くな ったものの, やはり完全には否定できないためレべル

\section{I までの郭清を行った。}

病理組織学的所見：腫瘍細胞は中型で淡明細胞から なり，アミラーゼ消化性の PAS 陽性物質 (glycogen) が多量に認められ，GRCCC と診断された（Fig. 4a). 増殖は scirrhous type で一部 papillo-tubular な形態 を示した。リンパ節は壊死と核崩壊産物を貪食した組 織球性細胞がみられ転移巣はなく, subacute necrotizing lymphadenitis の診断であった（Fig. 4b). ER 80 \%陽性, PgR 60\%陽性, HER2過剩発現なし, surgical margin free であった。

以上の結果より，残存乳房に対して $50 \mathrm{~Gy}$ の放射線 照射を行うとともに，TAM+LH-RH アナログの投 与を継続している。平成 23 年 1 月現在，左鎖骨上に触 知していたリンパ節は消失している.

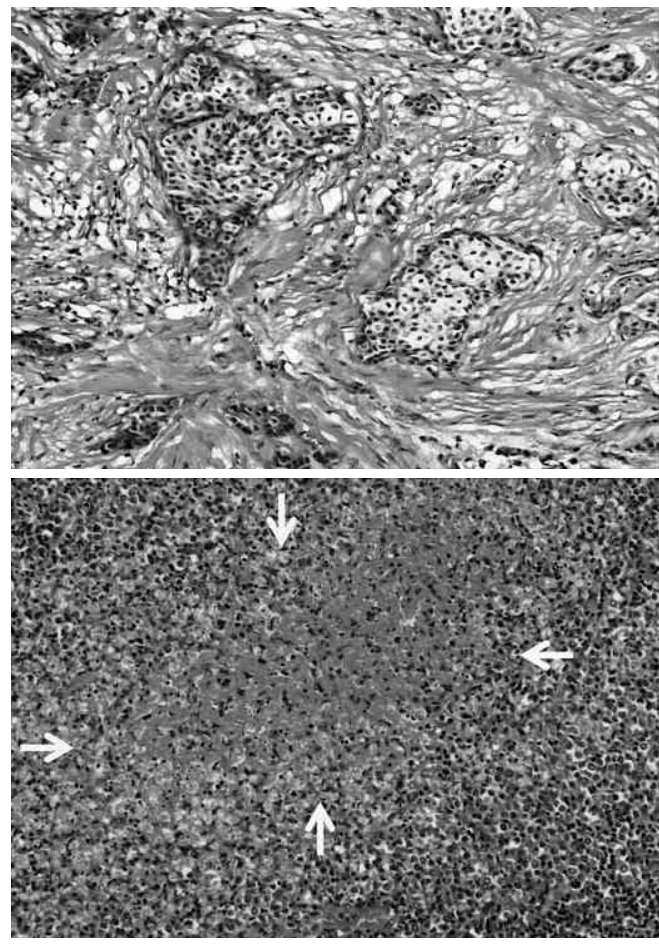

Fig. 4 Histological findings

a) Malignant tumor (H.E. stain $\times 400)$

Cancer cells show clear cytoplasm containing abundant glycogen granules.

b ) Left axillary lymph node (H.E. stain $\times 100$ ) Histiocytes engulfing necrotic substances are seen around the lesions of coagulation necrosis.

$\frac{\mathrm{a}}{\mathrm{b}}$

\section{考察}

乳腺 GRCCC は1981年に Hull ら ${ }^{4)} に よ り$ 最初に報 告された比較的まれな組織型であり，その発生頻度は $0.9 \sim 3 \%{ }^{12)}$ とされる．淡明細胞質を有する腫瘍細胞 が全体の $90 \%$ 以上を占め, 胞体内に PAS 染色で赤染 する多量のグリコーゲン顆粒を含み，これが diastase 消化 PAS 染色で消失することにより診断される ${ }^{3) 5)}$.

鑑別疾患として，脂質分泌癌，髄様癌，histiocytoid carcinoma などが淡明細胞で構成される場合や，腺筋 上皮腫，澄明細胞汗腺腫，印環細胞癌，転移性腎癌な ぞが挙げられる ${ }^{3 / 6)}$. Clear cell carcinoma の細胞質の 淡明化は, glycogen, lipid，mucin の貯留に起因する とされ，本症では glycogen 貯留がその原因とされ7), 腫瘍細胞での glycogen 代謝・合成に関わる酵素活性 
の異常とされる8).

穿刺吸引細胞診の特徵は比較的大型の腫瘍細胞で, 淡明な広い細胞質を有し $\mathrm{N} / \mathrm{C}$ 比は小さく核は円形 〜類円形で偏在しクロマチンは増量, 明瞭な核小体が 1 個認められる。本症例は細胞診で乳癌と確定診断し た。今回採取された腫瘍細胞は, 強いhyperchromatism を示し核径, 核型, 細胞結合性など, 総合 的に乳癌と診断するに充分足る内容であった. 結果乳 癌であり, 針生検等の組織診を経ず, 細胞診にて確定 診断としたことは，被検者への侵襲を減じる意味でも 妥当であったと考えている.

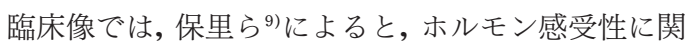
しては ER 陽性率が $34.3 \%, \mathrm{PgR}$ 陽性率は $34.4 \%$ であ り通常の乳癌に比べ本症のレセプター陽性率は低い。 一方, HER 2 は2 $2.1 \%$ で一般的な陽性率と変わらない と報告している. 予後については, Hayes ら ${ }^{5)}$ は腫瘍 径・リンパ節転移など臨床像が同程度であれば通常型 の浸潤性乳管癌と比して予後は変わらないと報告して いる. しかし, 逆に予後不良との報告もみられ, Toikkanen ら ${ }^{10)}$ はリンパ節転移率が高く予後不良としてお り, 見解は一定していない. 本症例は $\mathrm{ER}, \mathrm{PgR}$ ともに 陽性で HER2過剩発現なく, リンパ節転移もなく T1c, N0, M0：Stage I であり, 通常の方針に則って Tamoxifen と LH-RH アナログの併用を術後の補助 療法として継続中である。

亜急性壊死性リンパ節炎 (Subacute necrotizing lymphadenitis) ( ${ }^{11) ~ 13)}$, 比較的若い女性に発症し, 30 歳代までが全体の約 $85 \%$ を占める。一般に感冒様症状 を呈し発熱 $\left(38^{\circ} \mathrm{C}\right.$ 以上）とリンパ節腫脹を主徵とする ことが多い予後良好なリンパ節炎で， 1〜 3 カ月以内 に自然治癒する，悪性腫瘍ではないが腫脹したリンパ 節は比較的硬く触れるという特徵があり，圧痛を伴う ことが多い．検查所見では白血球減少が特徵で $4,000 /$ $\mathrm{cm}^{3}$ 以下を示すことが多く,まれに少数の異型リンパ 球の出現をみる. 白血球減少は主にリンパ球分画の減 少によるものである.

$\mathrm{CRP}$ 上昇, $\mathrm{LDH}$, トランスアミナーゼの軽度上昇を 伴い, その他血清中の interferon- $\gamma$, IL-2, IL-6の上 昇を認めることがある。本症例では白血球は $2,600 /$ $\mathrm{cm}^{3}$ と減少していたが分画は正常, LDH は260U/1 と 軽度上昇を示した. しかし, 臨床所見はリンパ節の腫 脹のみで発熱・圧痛などはなく, 年齢的にも非典型的 で本疾患を想定しておらず, CRP やサイトカインの検 查は行っていない. 今後本症例のように腫瘍とリンパ
節の所見に乘離を感じる際はこれら検査項目も考慮し てゆくべきと思われる。

組織像は多様であるが，あまり広範でないアポトー シスとみなされる凝固壊死巣を囲んで主として核崩壊 産物を貪食した組織球の出現があり, 周辺には芽球様 細胞の増生をみる ${ }^{14)}$. 本症の病因は不明であるが, 発症 機序としてウィルス感染あるいは自己免疫機構に基づ く cytotoxic T 細胞によるアポトーシスが考えられて いる ${ }^{11)}$. ウィルス初期感染に上昇する物質 (2'-5' oligoadenylate synthetase, 可溶性 Fas ligand 等) が 血清中で高值を示したり, 病巣に alpha-interferon 陽 性細胞が多く見られることなどから, ウィルス感染が 病因として強く疑われている ${ }^{15)}$ が, 原因ウィルスはい まだ明らかでない。

本症例では, 亚急性壊死性リンパ節炎を想定できず, ウィルス感染に関連した抗体価などの検査を行うには 至らなかった。また，欧米に比べアジア諸国で比較的 多く報告があり HLA-Class II遺伝子の相違が関与し ている可能性が指摘されている16).いずれにしてもア ポトーシスの機構を含め病因とその成立機序にはいま だ不明な点が多い。

本症には抗生物質は無効であり, 多くの症例は NSAIDsによる対症療法で自然治癒する. 症状が遷延 する例ではステロイド薬が奏効する.

本症例は初診時に近日中の発熱の既往や, 腫脹リン パ節に圧痛はなく, 病理結果で乳癌と同側の所属リン パ節群に亜急性壊死性リンパ節炎を併発していたこと が判明した。術前に腫瘍径とリンパ節の状態に乘離を 感じたため, 手術時の所属リンパ節郭清をどの程度に するかが問題となった. 臨床所見として複数のリンパ 節が顕著に腫脹しており, 仮にセンチネルリンパ節生 検を行ったとしても正常なリンパ流が維持されている かも不明で転移経路を通常のレベルで反映するかは不 透明であった。センチネル陽性であれば，定型的リン パ節郭清を行うが，センチネル陰性であっても腫脹し たリンパ節を残して郭清を縮小するのは現実的ではな いと考えた. 今回術中に迅速組織診を行ったのは, 転 移が確定した場合に定型的な腋窩郭清, 確定しない場 合は微小な転移の存在を考慮してレベル I のみに抑え るという方針を，術前に患者様と相談の上提案させて いただいたものである. 病理での検討でも転移巣は検 出されなかったが, 結果的には本症例においては妥当 な方針であったと考えている，また，以前にも両疾患 を併発し転移との鑑別に苦慮したとの症例報告がなさ 
れており ${ }^{17)}$ ，一方亜急性壊死性リンパ節炎の発症起因 として，その局所に存在する悪性腫瘍や異物などの抗 原性の関与を示唆する報告もある ${ }^{18)}$. 本症例も亜急性 壊死性リンパ節炎としては比較的高齢で非典型的であ り，片側の腋窩周囲にのみ発症し，偶然の併発という よりは何らかの局所的な病因が関与したと考えるほう が自然ではないかと思われた。

\section{結 語}

同側所属リンパ節に亜急性壊死性リンパ節炎を併発 し，リンパ節転移との鑑別が困難であった GRCCC の 1 例を経験した。

亜急性壊死性リンパ節炎の発症に, 本症例の乳癌細 胞が持つ何らかの抗原性が関与したのかは不明である が，本症例のごとく原発巣に照らし高度なリンパ節転 移が認められた場合，このような可能性も念頭に，問 診を含め慎重な診断・治療を進めることが必要と思わ れた。

\section{文献}

1) Hull MT, Warfel KA : Glycogen-rich clear cell carcinoma of the breast: A clinicopathologic and ultrastructual study. Am J Surg Pathol $1986 ; 10: 553-559$

2) Fisher ER, Tavares J, Bulatao IS, et al : Glycogen-rich clear cell breast canser: With coments concerning other clear cell variants. Hum Pathol $1985 ; 16$ : 1085-1090

3）土屋眞一, 秋山 太, 森谷卓也 : 乳腺病理カラー アトラス. 文光堂，東京，2008，p136-137

4) Hull MT, Priest JB, Broadie TA, et al : Glycogen-rich clear cell carcinoma of the breast: A light and electron microscopic study. Cancer $1981 ; 48$ : 2003-2009

5) Hayes MMM, Seidman JD, Ashton MA : Glycogen-rich clear cell carcinoma of the breast: clinicopathologic study of 21 cases. Am J Surg Pathol $1995 ; 19: 904-911$

6) 土屋眞一, 伊藤 仁 : カラーアトラス 乳腺細胞 診。医療科学社, 東京, 2000, p248一 249
7）安田政美, 佐藤文子, 梅村しのぶ：Glycogen-rich clear cell carcinoma. 病理と臨 $2001 ； 19 ： 500$ $-503$

8）藤吉行雄，栄本忠昭：乳腺 glycogen-rich clear cell carcinoma $の 1$ 例. 病院病理 $1998 ; 15$ ： 104

9) 保里惠一, 成田 洋, 齋尾征直 : 乳腺 glycogenrich clear cell carcinoma の 1 例. 日臨外会誌 $2008 ; 69: 2173-2177$

10) Toikkanen S, Joensuu $H$ : Glycogen-rich clear cell carcinoma of the breast: A clinicopathologic and flow Cytometoric study. Hum Pathol $1991 ; 22: 81-83$

11）安部正文：組織球性壊死性リンパ節炎. 別冊日本 臨牀 領域別症候群, 32, 免疫症候群 (下巻), 日 本臨牀社，大阪，2000，p541-543

12）脇本直樹: 特集 専門医へのコンサルト リンパ 節腫脹。内科 $2009 ; 104: 1309-1314$

13）徳永博俊，杉原 尚：プライマリケア時代の症候 の診かた リンパ節腫脹。診断と治療 2008 ; 96(増刊)：403-408

14）飯島宗一, 景山圭三, 石川栄世他：組織病理アト ラス. 文光堂，東京，1987，p436

15) Sumiyoshi $Y$, Kikuchi M, Takeshita M, et al: Alpha-interferon in Kikuchi's disease. Virchows Arch B cell Pathol 1991;61 : 201-207

16) Tanaka $T$, Ohmori $M$, Yasunaga $S$, et al : DNA typing of HLA class II genes (HLA-DR, -DQ, DP) in Japanese patients with histiocytic necrotizing lymphadenitis (Kikuchi's disease). Tissue Antigens $1999 ; 54: 246$-253

17）大谷陽子, 吉留克英，赤松大樹他：乳癌リンパ節 転移と鑑別を要した壊死性リンパ節炎の 1 例。日 臨外会誌 $2008 ； 69$ (増刊号) : 619

18) Apel NM, Peters EE : Kikuchi's disease in axillary lymph nodes draining breast carcinoma. Histopathology $2000 ; 36: 280-281$ 


\title{
A CASE OF MAMMARY GLAND GLYCOGEN-RICH CLEAR CELL CARCINOMA ASSOCIATED WITH SUBACUTE NECROTIZING LYMPHADENITIS REQUIRING DISTINCTION FROM LYMPH NODE METASTASIS
}

\author{
Fumihiko SATOH, Minoru OKAZAKI, Akira OKAZAKI, \\ Yoshiki WATANABE and Eimei NARIMATSU* \\ Sapporo Breast Surgery Clinic \\ *Sapporo Medical Laboratory INC.
}

The patient was a 50-year-old woman. Screening mammography (MMG) had indicated an abnormal shadow in the right breast. A repeat MMG revealed no abnormality, but ultrasonography (US) showed a tumor in the C-region of the contralateral left breast, which was suspected to be a malignancy based on the results of fine needle aspiration cytology (FNAC). The patient was therefore referred to our hospital for complete evaluation and treatment.

She was confirmed to have breast cancer by repeat FNAC, and an enlarged lymph node was palpable in the axilla and over the collar bone. The presence of a metastatic lymph node seemed somewhat unlikely, judging from the size of the primary tumor on US. Thus, FNAC of the axillary lymph node was performed, but no metastasis was detected. After admission, left-breast-conserving surgery (lt-Bp $+\mathrm{Ax})$ was performed. Histopathology revealed a glycogen-rich clear cell carcinoma, and the lymph node showed subacute necrotizing lymphadenitis.

Key words : glycogen-rich clear cell carcinoma, subacute necrotizing lymphadenitis 